\title{
Mould Contamination Experimental Study in Public Building Environment
}

\author{
Xin Zhang ${ }^{1}$, Guojie Chen ${ }^{1}$, Xuanhao Ran ${ }^{1}$,Yaqian Huang ${ }^{2}$, Huaihao Wang ${ }^{3}$ and Lijiao Tang ${ }^{4}$ \\ ${ }^{1}$ School of Architecture and Construction, University of South China(USC), Hengyang, Hunan Province,China Postcode:421001 \\ ${ }^{2}$ Hengyang Medical College, University of South China(USC), Hengyang, Hunan Province,China Postcode:421001 \\ ${ }^{3}$ The Institute of Nuclear Science and Technology, University of South China(USC), Hengyang, Hunan Province, China Postcode:421001 \\ ${ }^{4}$ School of Mechanical Engineering, University of South China(USC), Hengyang, Hunan Province,China Postcode:421001
}

\begin{abstract}
This paper is aimed at the experimental study on mould contamination status. Mold contamination has seriously threatened residents' physical and mental health and buildings. However, few experimental studies on mold contamination was made in the built environment under hot and humid climate. We firstly prepared the Sabaurauds agar(SAB) with reference to the national standard and set sampling points by the five-point sampling method in a classroom of USC. Then, we cultured the sample in $28{ }^{\circ} \mathrm{C}$ constant temperature condition, counted mould number with plate counting method and referred to the Omeilianski formula to calculate indoor mould concentration. The study found that the average concentration of mould spore in the typical public building was $629 \mathrm{cfu} / \mathrm{m}^{3}$, and the exceeding rate was up to 25.8\%. The results show that the typical public building environment in Hengyang has serious mould contamination, thus further environmental optimization research is urgently needed.
\end{abstract}

\section{Introduction}

With the rapid development of China's construction industry in recent years, building environment problems have become increasingly prominent, among which mould contamination is a key problem, especially in the humid and hot climate areas in south China. The humid and hot climate in the south provides favorable conditions for mould breeding.

Mould contamination in building environment has a detrimental effect to buildings and residents. Mould can make metamorphism, degradation, decomposition, corrosion and crack to building materials, which disable their original function, produce the mildew on the wall and cause the external wall surface of the building to bulge and its insulation material to fall off $[1,2]$. The service life and aesthetics of the wall are seriously affected. Mould growth can cause Sick Building Syndrome (SBS), which leads to high renovation costs [3-4]. Long-term exposure to mould environment can easily cause respiratory diseases and allergic symptoms, such as bronchitis, asthma and allergic pneumonia. For the elderly and children with low immunity, mould may also cause headache, fever, inflammation of skin or mucous membrane and other diseases [5]. The mycotoxin produced by mould in the process of metabolism is more harmful to human body and damages human nervous and immune system.

According to the World Health Organization (WHO), more than $80 \%$ of the world's residences have molds in varying degrees. Due to the influence of many factors such as climatic conditions, building quality and indoor environment, mould contamination in Chinese residential buildings is particularly serious. Wei [5] found in their indoor mould investigation in Shanghai that the housing with mould accounted for $56.3 \%$, and the housing with serious mould contamination accounted for $16.9 \%$. Liu [6] conducted a questionnaire survey on 15,266 students and found that the incidence of visible mould and mouldy odor in Shanghai residential buildings was $7.9 \%$ and $11.9 \%$ respectively. Yuan [7] investigated the indoor mould contamination status of 16 buildings, 12 bungalow houses and 6 office buildings in Dongzhimen district, Beijing, in which indoors mould contamination was found to varying degrees, and the mould contamination in summer was higher than that in winter. $\mathrm{Li}$ [8] investigated the atmospheric microbial contamination in Nanning city and found that the range of atmospheric microbial content in the urban area was $1101-29094 \mathrm{cfu} / \mathrm{m}^{3}$, among which mould accounted for 20.8\%.Lin[9]investigated the air microbial contamination in urban areas of Jiaxing city and found that the counts of bacteria and mould in the air were 568$4630 \mathrm{cfu} / \mathrm{m}^{3}$ and $507-5347 \mathrm{cfu} / \mathrm{m}^{3}$, accounting for $47.4 \%$ and $52.6 \%$ of the total number of airborne microorganism, respectively.

In this paper, the typical public buildings in Hengyang, which belongs to the typical hot and humid climate area, were studied by experimental test. The results have a good reference to the mould research in other humid and hot climate areas.

\footnotetext{
* Corresponding author: cgjsccgj@126.com
} 


\section{Mould test in building environment}

We selected a classroom on the first floor of the fifth teaching building in USC, Hengyang as the research object. The fifth teaching building is a brick and concrete structure, six stories high, which has existed for 20 years . It is orientated south and north, shaded by other buildings and greenery, and has good ventilation. Mould contamination in construction is positively correlated with the concentration of mould spore in the air, thus we sampled indoor mould spores to evaluate indoor mould contamination $[10,11]$. At the same time, we recorded the related factors of building characteristics and indoor environment. The actual measured time was December, 2018.

SAB medium was prepared with reference to Examination Methods for Public Places with Chinese standards (EMPP)(GB/T 18204.4-2013) [12]. The main components were: $0.5 \mathrm{~L}$ distilled water, $5 \mathrm{~g}$ peptone, $20 \mathrm{~g}$ glucose, $10 \mathrm{~g}$ agar, and $0.05 \mathrm{~g}$ chloromycetin. We mixed the above ingredients together even after adjusting the $\mathrm{pH}$ to $5.6 \pm 0.2$ and bottled under $115^{\circ} \mathrm{C}$ high pressure sterilization for 15 minutes. After being cooled to an appropriate temperature, the culture medium was poured into a glass plate with a diameter of $90 \mathrm{~mm}$ according to $20 \mathrm{ml}-25 \mathrm{ml}$ per plate. After the agar in the culture medium was solidified, it was put into a culture box for 24 hours to observe whether there were bacterial colonies. If there were bacterial colonies, it was discarded.

We used the natural sedimentation method to test the number of mould spores in indoor air. According to the five-point sampling method, we set five sampling points. Each sampling point is $1.2 \mathrm{~m}$ to $1.5 \mathrm{~m}$ away from the ground and more than $1 \mathrm{~m}$ away from the wall. The mediums were exposed to the environment for $5 \mathrm{~min}$, and a group of medium was randomly placed with parafilm as control group. After sampling, we covered the lid, inverted the plate and sealed it with parafilm to prevent contamination of bacteria during culture. After the sealed plate was placed in a constant temperature environment of $28{ }^{\circ} \mathrm{C}$ for 72 hours, the mold in the plate was counted. Since temperature and humidity have a major impact on mold growth and spore release, it is necessary to record changes in indoor temperature and humidity. The temperature and humidity recorder was placed at a height close to the sampling point while sampling the mould. The automatic recorder recording interval is $30 \mathrm{~min}$, and the recording time is $24 \mathrm{~h}$ after the start of sampling.

The main equipment and instruments for the experimental test were: electronic analytical balance (AUY220D), whose measuring range is from 0.01 to 220g; Biochemical incubator (PVX-250S-C); Autoclave sterilizer (GI54TW), as shown in figure 1.

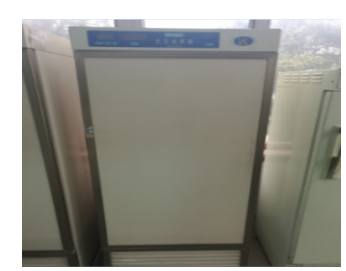

a) Biochemical incubator

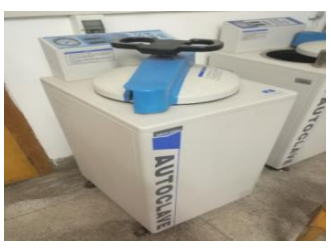

c) Autoclave sterilizer

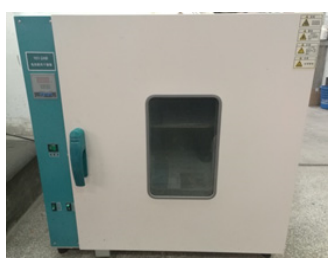

b) Electric Blast Drying Oven

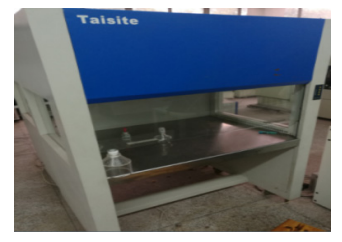

d) Asepsis work table
Fig 1. Main instruments and equipments

\section{Test results and analysis}

The matrices in the 6 petri dishes were taken from the same batch of prepared medium, and the contents of each petri dish were consistent. The 6 petri dishes were disinfected and sterilized simultaneously while taken out, and were randomly numbered. The counting method was in accordance with the plate counting method in GB/T 18204.4-2013 EMPP [12]. The results of mould counting in petri dishes were shown in table 1 . The real-time growth of mould in each petri dish was shown in the table:

Table 1. Count of bacteria on petri dishes

\begin{tabular}{|c|c|c|c|c|c|c|}
\hline Time & No.1 & No.2 & No.3 & No.4 & No.5 & $\begin{array}{c}\text { Control } \\
\text { group }\end{array}$ \\
\hline Begins & 0 & 0 & 0 & 0 & 0 & 0 \\
\hline $12 \mathrm{~h}$ & 0 & 0 & 0 & 0 & 0 & 0 \\
\hline $24 \mathrm{~h}$ & 0 & 0 & 0 & 0 & 0 & 0 \\
\hline $48 \mathrm{~h}$ & 6 & 5 & 3 & 1 & 4 & 0 \\
\hline $72 \mathrm{~h}$ & 10 & 12 & 7 & 6 & 13 & 0 \\
\hline $\begin{array}{c}\text { The } \\
\text { mean } \\
\text { value of } \\
72 \text { hours }\end{array}$ & \multicolumn{7}{|c}{9.6} & & 0 \\
\hline
\end{tabular}

The petri dish was incubated at a constant temperature for $24 \sim 48$ hours. At the 48 th hour, petri dish No. 1 was observed to have the most colonies, No. 3 dish and No. 4 dish had few colonies, and No. 4 dish had a single large white trichome colony, but other colonies in NO. 4 dish were small. After 72 hours, 10 colonies were observed in No.1 petri dish; 12 in No.2 petri dish; 7 in No.3 petri dish , 6 in No.4 petri dish, and 13 in No.5 petri dish. No mould growth was observed in the control group. There was no significant difference in mould in the petri dishes except that No.4 had a large colony. We suspected that the sampling points No.2 and No.5 were 
close to the corner of the wall, and the wall is seriously polluted by mould. Therefore, the results show that No.2 and No.5 have a large number of mould colonies. No.3 and No.4 sampling points are close to the corridor and ventilated, and the results show that No.3 and No.4 have a small number of mould colonies. The distribution of mould in No.5 dish was shown in figure 2.

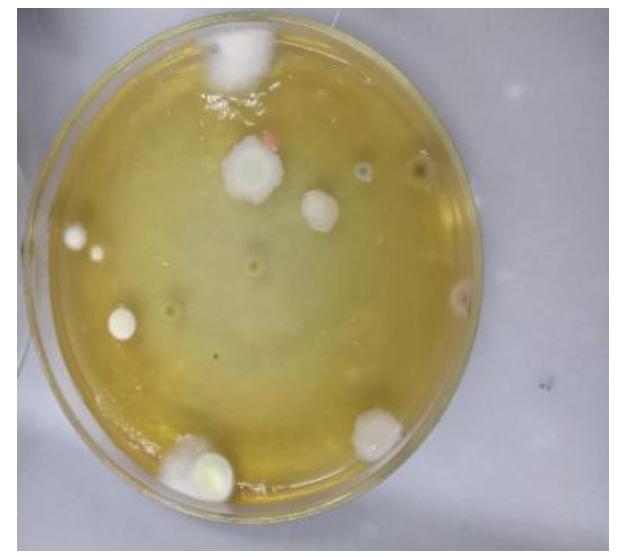

Fig 2. Distribution of mould in petri dish No. 5

According to Omeilianski's suggestion, the total number of microbes falling into $100 \mathrm{~cm}^{2}$ plates within $5 \mathrm{~min}$ is equal to the total number of microbes in $10 \mathrm{~L}$ of air. The indoor mould concentration was calculated by the Omeilianski formula, as shown in the following formula.

$$
C=N \times \frac{100}{A} \times \frac{5}{t} \times \frac{1000}{10}=\frac{50000 N}{A \times t}
$$

In this formula: $C$ is the microbial concentration in the environment, $\mathrm{cfu} / \mathrm{m}^{3} ; N$ is the average number of colonies in the dish, number per dish; Is the area of the dish, $\mathrm{cm}^{2} ; t$ is sampling time, min.

By substituting the experimental results into the above formula, we obtained the average mold concentration in the measured house as $629 \mathrm{cfu} / \mathrm{m}^{3}$. WHO suggested that $500 \mathrm{cfu} / \mathrm{m}^{3}$ should be taken as the threshold value of indoor mould spore concentration to determine whether there is mould contamination. This experiment detected that the total number of mould colonies in typical public building environment in Hengyang exceeded the standard rate by $25.8 \%$, indicating that there is serious mould contamination in the building environment.

\section{Conclusion}

The SAB medium was prepared with reference to EMPP (GB/T 18204.4-2013), and a classroom on the first floor in USC was selected as the sample room. The sampling point was set by five-point sampling method, and the sampling time was $5 \mathrm{~min}$. Then, the sample was plated in a $28^{\circ} \mathrm{C}$ temperature condition. The counting method was in accordance with the plate counting method. After $72 \mathrm{~h}$, we found that No.2 and No.5 medium had a large number of mould colonies, and No.3 and No.4 medium had a small number of mould colonies. It may be that sampling points No. 2 and No.5 are close to the corner of the wall, where has serious mould contamination, while sampling points No.3 and No.4 are close to the corridor and ventilated, so the number of mould colonies is small. This fully proves that there is a positive correlation between construction mould contamination and the concentration of mould spore in the air.

In this paper, mould spore concentration in the air of typical public buildings in Hengyang was tested experimentally, so as to study mould contamination in the building environment. The indoor mould concentration was calculated according to the Omeilianski formula, and the measured results show that the average mould spore concentration is $629 \mathrm{cfu} / \mathrm{m} 3$, which is higher than the threshold of spore concentration. This indicates that there is serious mould contamination in the sampling site. The results can be used as a reference for the study of mould contamination in building environment in hot and humid climate.

\section{Acknowledgement}

This work was supported by Natural Science Foundation of China (Grant no.51408294, 51876087, 51708271), Key Research Foundation of Hunan Province(Grant no.2017SK2394), Hunan Provincial Natural Science Foundation of China (Grant no.2019JJ40261), Doctor Launched Foundation of The University of South China(Grant no.2017XQD02).

\section{References}

1. H. D. Tang, J. H. Ding, C. Y. Li, J. X. Li. A field study on indoor environment quality of Chinese inpatient buildings in a hot and humid region[J].Build Environ, 151, 15:156-167(2019)

2. W. J. Chen, D. E. Claridge, C. Rohrs, J.J. Liao. Modeling to predict positive pressurization required to control mold growth from infiltration in buildings in a hot and humid climate[J].Build Environ, 104, 1:102-113(2016)

3. A. Célia, D. Márcio, F. Marina, A. Artur, A. Adelaide, C. H. Ângela. Air quality in a school with dampness and mould problems[J].Air Qual Atmos Hlth,25,6: 1873-9318 (2015)

4. K. Emma, P. Tuula, S. Susanna. Indoor Air Problems and Hoarseness in Children [J].J Voice, 30,1 :109-113 (2016)

5. X.Y. Wei, X. Han, Y.Y. Cui, Y.W. Zhang, H. Chen, Investigation on mould growth on indoor wall surfaces of residential buildings in Shanghai[J]. Building thermal ventilation and air conditioning, 35(01) (2016) 27-30+26.

6. W. Liu, C. Huang, Y. Hu, L. Shen, J. Sundell. Associations of building characteristics and lifestyle behaviors with home dampness-related exposures in Shanghai dwellings [J]. Build Environ, 88,1:106-115 (2015) 
7. Y.L. Yuan, N.Y. Zhu. Investigation on indoor mould contamination of ordinary residents in dongzhimen district Beijing [J]. Disease surveillance, 11: 433-435 (2003).

8. J.Q. Li, F.K. Shen, Y.X. Luo, Z.Y. Meng. Investigation and evaluation of atmospheric microbial contamination in Nanning city [J]. Science of environmental protection,4:8-10 (2007).

9. X. Lin, X. Yin, L.X. Wang, S.L. Xu.Investigation on air microbial contamination in urban areas of jiaxing city $[\mathrm{J}]$. Zhejiang preventive medicine, 5 :6-7 (2003)

10. J. A. Crawford, P. F. Rosenbaum, S.E. Anagnost. The Indicators of the fizzy fungal concentrations in urban homes[J].Sci Total Environ, 517:113-124 (2015)

11. GB/T 18204.4-2013.Sanitary inspection methods for public places -- part 4: microorganisms in public articles [S].

12. GB/T 18883-2002. Standard for indoor air quality [S]. 